\title{
2.2 Методичні підходи до оцінки інвестиційної привабливості: регіональний аспект
}

У сучасних умовах залучення інвестицій $є$ важливим завданням та одним iз головних складників розвитку національної економіки. Передумовою ефективної інвестиційної діяльності є аналіз і оцінка привабливості об'єктів інвестування 3 метою визначення орієнтирів та пріоритетів для надходження інвестицій. Інвестиційна привабливість $є$ важливим складником стратегії сталого економічного розвитку держави, тому ії дослідження та оцінка мають велике теоретичне та практичне значення.

Оцінка інвестиційної привабливості держави або регіону є важливим моментом для іноземного інвестора під час прийняття важливих управлінських рішень. Нажаль сьогодні в Україні інвестиційна діяльність з огляду на військові ризики на сході країни зазнала певної деградації. То ж сьогодні стан інвестиційної привабливості як всієї України так і окремих ії регіонів є досить складним в наслідок як світової фінансової кризи, так і внутрішніх військових ризиків а також дефіциту інвестиційних ресурсів та можливостей бюджетів усіх рівнів.

Питання методології оцінки інвестиційної привабливості та інвестиційного клімату постійно перебувають у полі зору вітчизняних дослідників, зокрема таких, як А. Асаул, А. Гайдуцький, О. Дудчик, I. Пашикян, А. соловйова, О Носова та ін. Сьогодні існує чимало різних методик оцінки інвестиційної привабливості економіки, що розглядають переважно окремі іï рівні. Проте, з огляду на існуючі методичні підходи оцінювання інвестиційної привабливості, можна стверджувати, що вони не враховують повною мірою особливості різних рівнів економіки, мало узгоджені між собою, мають різний методологічний підхід і тому не можуть використовуватися для комплексної оцінки. Разом із тим, аналіз вищенаведених джерел вказує на те, що певний перелік питань, пов'язаних з оцінкою інвестиційної привабливості регіонів, вивченням факторів та резервів ії підвищення, їх прогнозуванням, залишаються 
невирішеними.

Головними орієнтирами інвестування $є$ фактичний і потенційний розміри місцевих ринків, економічна і правова стабільність у регіонах. Найбільш пріоритетним напрямом є інвестування в об'єкти, що вже освоєні, оскільки створена інфраструктура значно сприяє подальшому їхньому розвитку. Для України нині найбільш важливими є такі галузі й сфери, що вимагають реструктуризації і додаткових капітальних вкладень.

У результаті проведеного дослідження теоретико-методичних основ поняття «інвестиційна привабливість» визначено, що це інтегральна характеристика умов та чинників 3 позиції перспективності створення інвестиційного клімату, достатнього рівня розвитку ринкової та соціальної інфраструктури, реальних можливостей отримання інвестиційних ресурсів та реалізації інших факторів, які суттєво впливають на формування прибутковості інвестицій і обмеження інвестиційних ризиків [19].

Інвестиційні потоки обслуговують економічно розвинуті регіони України, лишаючи поза увагою менш розвинуті регіони, що потребують значного надходження іноземних інвестицій. Таке спрямування прямих іноземних інвестицій у регіональному розрізі не сприяє рівномірному соціальноекономічному розвитку країни та посилює подальше збільшення регіональних диспропорцій. Задля усунення цих проблем повинна бути сформована виважена та дієва державна інвестиційна політика, спрямована на збільшення інвестиційної привабливості регіонів України.

Основними причинами диспропорцій інвестиційної активності по регіонах України є відсутність програм соціально-економічного розвитку в значної кількості територіальних громад (малих міст, селищ, сіл), а отже, недостатня визначеність пріоритетів розвитку таких територій; втручання уряду в роботу приватного бізнесу та значні адміністративні перешкоди для розвитку інвестиційної діяльності; відсутність регіональної системи маркетингу та промоції, недостатня розвиненість інфраструктури підтримки та системи інформаційного забезпечення інвестиційної діяльності; недостатній рівень 
кадрового потенціалу органів місцевого самоврядування та державної служби, задіяного в інвестиційних процесах на регіональному та місцевому рівнях; військовий конфлікт на сході України. Отже, необхідною передумовою сталого соціально-економічного розвитку в регіонах та забезпечення якісного економічного зростання в державі $\epsilon$ висока інвестиційна активність, яка досягається не тільки шляхом збільшення реалізованих інвестиційних ресурсів, але й за рахунок їх ефективного використання у пріоритетних секторах економіки.

Формування інвестиційної привабливості залежить від впливу чинників, представлених у табл 1. [18].

Таблиияя 1

Чинники, що визначають економічну привабливість регіону

\begin{tabular}{|c|c|l|}
\hline $\begin{array}{c}\text { № } \\
\text { п/п }\end{array}$ & Чинники & \multicolumn{1}{|c|}{ Характеристика } \\
\hline 1. & $\begin{array}{c}\text { Загальні } \\
\text { (характеризують } \\
\text { інвестиційнй клімат) }\end{array}$ & $\begin{array}{l}\text { визначають політичну фінансову стабільність, правовий захист } \\
\text { інвестора, розвиток інфраструктури, ринкові відносини, рівень } \\
\text { ризиків, питому вагу державного сектору; }\end{array}$ \\
\hline 2. & $\begin{array}{c}\text { Галузеві } \\
\text { (за видами економічної } \\
\text { діяльності) }\end{array}$ & $\begin{array}{l}\text { визначають рівень капіталомісткості, оборотності і віддачі } \\
\text { засобів, що було вкладено у визначений вид діяльності; }\end{array}$ \\
\hline 3. & $\begin{array}{c}\text { Територіальні } \\
\text { 2арактеризують наявність сировини, робочої сили, транспортного } \\
\text { сполучення, ринки збуту, клімат, природно-економічні умови } \\
\text { виробництва тощо; }\end{array}$ \\
\hline & Індивідуальні & $\begin{array}{l}\text { Визначають рейтингову оцінку, місце розташування, земельну } \\
\text { площу, наявність виробничих потужностей, показники балансу } \\
\text { суб'єкта (прибутковість, ліквідність, стабільність), оцінки ризиків } \\
\text { та ін. }\end{array}$ \\
\hline
\end{tabular}

Оцінка інвестиційної привабливості повинна здійснюватися комплексно шляхом співставлення аналітичних та прогнозних показників, що дасть змогу інвестору прийняти рішення стосовно доцільності вкладення капіталу.

Існують різні методи та підходи оцінки інвестиційної привабливості регіону. Існуючі методики можна поділити згідно двох класифікаційних ознак: методів обробки даних та відповідної системи показників. Так згідно методів обробки даних існує два основних підходи - описовий та рейтинговий.

Описовий підхід полягає в описі абсолютних показників, структури та динаміки показників розвитку регіону. Експерт самостійно обирає найбільш значущі показники та формує на їх основі висновки щодо інвестиційного клімату 
в регіоні. Переважно такий аналіз базується на дослідженні соціальноекономічного розвитку регіону [18].

Рейтинговий підхід грунтується на опитуванні відповідних суб'єктів економічної діяльності регіону, під час якого визначають відповідні напрям впливу та ступінь впливовості певних факторів. Зазначені опитування підлягають угрупованню, і потім за інтегральним показником формується загальний рейтинг регіону. Зазначена методика широко розповсюджена на практиці у провідних світових аналітичних та консалтингових агенцій.

Серед усіх підходів до оцінки інвестиційної привабливості регіону саме рейтинговий метод набув найбільшої популярності завдяки простоті використання та забезпеченню задоволення інформаційних потреб різних суб’єктів інвестиційного та суспільно-економічного процесу.

При використанні описового підходу оцінка може надавати відповідні змістовні результати, проте це вже перебуває в залежності від кваліфікації того аналітика, котрий проводить відповідний аналіз. Але зазначена методика потребує від автора збору великого обсягу інформації із різноманітних аспектів їх ранжування та діяльності за рівнем впливу на інвестиційну привабливість. Тут варто зауважити, що отримані під час застосування описового підходу результати, є досить складними для подальшого аналізу.

Рейтинговий підхід дає більш наочний результат, а процес оцінки є не таким громіздким, як у першому підході. Результат подається у вигляді інтегрального показника інвестиційної привабливості регіону, який лише показує місце регіону серед інших і не вказує напрямів інвестування на цій території, тобто галузі пріоритетного фінансування [21].

Пропонуємо авторську методику оцінки інвестиційної привабливості (IП) регіонів, що складається з декількох взаємопов'язаних етапів, які представлені на рис. 1.

Оскільки завдання інвестора полягає у виборі найбільш привабливого об'єкта інвестування, то для наочності результати оцінки інвестиційної привабливості досліджуваних регіонів ранжируються шляхом порівняння 
показників по кожному фактору між собою і присвоєння місця у відповідності зі значенням показника. Але при оцінці фінансового стану регіону підхід є іншим, оскільки грунтується на визначенні сумарних коефіцієнтів відхилень значень кожного порівнюваного показника від еталонної величини, в якості якої беруться їх нормативні значення.

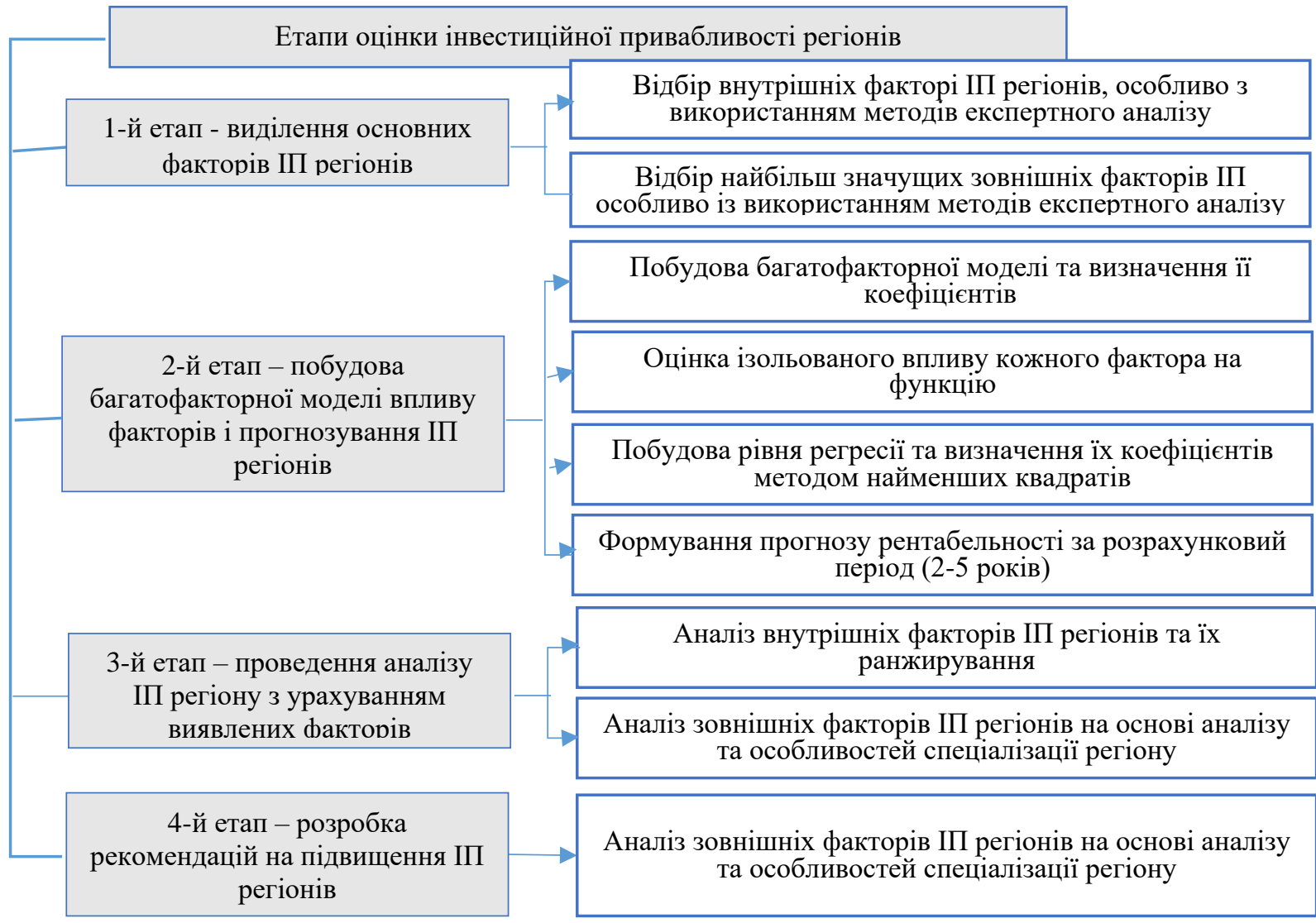

Рис. 1. Методика оцінки інвестиційної привабливості регіону

Джерело: сформовано авторами

В основу розрахунків покладено методику, яка спирається на стандартні статистичні операції, що дозволяють уніфікувати етапи роботи. 3 метою досягнення співставності показників, вони трансформуються до одного масштабу шляхом ділення кожного із значень показника на максимальну (оптимальну) величину. Розрахунок сумарного коефіцієнта (А) по ј-му регіону здійснюється за формулою:

$$
A_{j}=\sqrt{\sum_{t}\left(1-\frac{a_{i j}}{\max a_{i}}\right)^{2}}
$$

де aij - значення i-го показника ј-го регіону; 
max ai - еталонне (максимальне) з порівнюваних значень i-того показника.

Найвищий рейтинг у цьому випадку буде у регіону 3 мінімальним значенням коефіцієнта. Рівень активності інвестиційної діяльності часто пов’язують 3 поняттям «інвестиційного клімату» держави і іï територіальних громад. Оцінка інвестиційного клімату виступає в якості ринкового інструменту оптимізації потоку капіталовкладень.

Економічний термін «інвестиційний клімат» дозволяє визначити ту систему орієнтирів, у межах якої відбувається процес інвестування, і на основі цього намітити напрями ефективного використання інвестицій. Він включає стан економіки, соціально-економічну стабільність, рівень розвитку законодавчої бази, рівень розвитку інвестиційної інфраструктури, рівень розвитку продуктивних сил, валютну і фіскальну політику, стан фінансово-кредитної системи та інвестиційного ринку, інвестиційну активність населення, статус іноземного інвестора та інші фактори [20].

У наукових колах і серед підприємців існує багато версій визначення поняття «інвестиційний клімат». Так, переважна більшість економістів трактує інвестиційний клімат як сукупність соціальних, природних, економічних, політичних або інших передумов, які характеризують доцільність інвестування в ту чи іншу діючу господарчу систему і погоджується з тим, що це - комплексне економікополітичне явище, що формується під впливом значної кількості чинників [19]. Такі фактори, як правило, піддаються адекватній кількісній оцінці, i відтак - i порівняльному аналізу, який дозволяє ідентифікувати рівень інвестиційної привабливості певного регіону на фоні інших регіонів держави [18].

Необхідною та важливою передумовою у формуванні сприятливого інвестиційного клімату виступає інвестиційна привабливість регіону. Наразі існує велика кількість підходів до оцінки інвестиційної привабливості регіонів. Індикатори інвестиційної привабливості є дуже різноманітними. У світовій практиці подібні розробки набули значного поширення, над цими проблемами працюють спеціалізовані наукові центри. В Україні, як уже зазначалось, відсутня 
аналогічна загальновизнана методика для оцінки інвестиційної привабливості регіонів.

Аналіз і використання накопиченого досвіду у сфері розробки методик оцінки інвестиційного клімату $є$ дуже важливим. В основі практично усіх західних методик лежить використання різних методів оцінки інвестиційних ризиків. До найбільш розповсюджених методів оцінки ризику відносять: інспекційні поїздки експертів, метод розвідки, кількісні методи.

Наприклад, лондонський фінансовий журнал «Euromoney» розраховує інтегральний показник надійності, що вимірюється по стобальній шкалі [21]. У США регулярно публікуються індекси, що характеризують рейтинг штатів за різними критеріями (політичним, економічним, соціальним, екологічним). Рейтинги інвестиційної привабливості регіонів активно розробляють спеціальні наукові центри типу «The Wall Street Journal», «Financial Times», «Investor's Daily»».

Найбільш відомими системами оцінок інвестиційного клімату є рейтинги Institutional Invest or, Euromoney Institutional Investor, Business Enviroment Risk Index (BERI). Ці рейтинги - насамперед оцінка кредитоспроможності країни.

Американська дослідницька організація «Еconomist Group» оцінює рівень інвестиційної привабливості країни щодо інвестиційного ризику. При цьому були враховані чотири основних фактори: структура політичної влади, економічна політика, розмір зовнішнього боргу і ситуація в банківській системі країни.

Інститут реформ для визначення інвестиційної привабливості України використовує методику визначення стандартизованих значень (балів) кожного 3 показників по регіонах [20].

Можна зробити висновок, що зарубіжні системи оцінки інвестиційного клімату мають загальні переваги, які полягають у тому, що всі вони виступають в якості відповідного орієнтиру для іноземних фінансових організацій. Серед недоліків варто виділити наявність суб’єктивізму та відсутність належного рівня конкретності, а також слабкий рівень галузевої спеціалізації. Зазначені недоліки 
мають місце через те, що системи спрямовані здебільшого на орієнтацію інвестора під час початкової стадії інвестиційної діяльності. Потреба в оцінці інвестиційного клімату на рівні регіонів і їі облік при проведенні рейтингу держави в цілому необхідні, особливо в умовах самостійності територій. То ж в подальших розвідках стає актуальним проведення аналізу сутності інвестиційного процесу в сучасній економіці і його залежності від базових характеристик соціально-економічної системи регіону, а також аналізу статистичного взаємозв'язку відібраних показників 3 показником фактичної інвестиційної привабливості. 